\title{
From the Editor:
}

Slavic Review publishes letters to the editor with educational or research merit. Where the letter concerns a publication in Slavic Review, the author of the publication will be offered an opportunity to respond. Space limitations dictate that comment regarding a book review should be limited to one paragraph; comment on an article should not exceed 750 to 1,000 words. The editor encourages writers to refrain from ad hominem discourse.

D.P.K.

\section{To the Editor:}

I wish to thank Lars Lih for attacking my book The Soviet Tragedy in the Spring issue (Slavic Review 56, no. 1). His criticism was that my "misreading" of Bukharin's $A B C$ of Communism did "irreparable damage" to the book's thesis that Marxism "mandated" a revolutionary "leap into socialism" in Russia. At least this got the book and its thesis mentioned for the first time in the profession's premier journal and thus offers, so to speak, the functional equivalent of the review that never appeared there. But is Lih so certain that my reading of Bukharin (like Andrzej Walicki's and Leszek Kolakowski's - two pretty big guns, after all) is mistaken? In fact, it is quite similar to Lih's own reading of Stalin's letters to Molotov, published by Yale University Press, a reading that shows most plausibly the Leader to be a true believer in his own "cause"which was precisely a revolutionary leap into socialism. And Stalin believed this because instant socialism following the proletarian seizure of power was the creed, not only of the young Bukharin and Lenin, but also of the "moderate" German SDsindeed of all Marxists back to Marx himself. Which brings me to the real point: when is the profession's premier journal going to recognize that since communism's collapse the regnant social explanations of its career are open to the most serious question? What is required now is a real debate on this Big Question, not a few barbs in footnotes against books whose existence Slavic Review has never acknowledged.

MarTin E. Malia University of California, Berkeley

Lars T. Lih replies:

Martin Malia and I think alike on several major issues: I believe as he does that the Bolshevik leaders were by and large sincere believers in socialist doctrine, that the study of doctrine has unfortunately been neglected for several decades, and that a debate is needed on all these issues. My article on the $A B C$ of Communism was in fact meant as a contribution to the discussion of this Big Question (and I should mention that my comments on Malia's views were in fact more extensive than the barbed footnotes he mentions). Malia expresses skepticism that Lars Lih could be right when various "big guns" of the profession are wrong. I myself am puzzled by this-I entitled my article "The Mystery of the $A B C$ " for just this reason-but I am encouraged that Malia provides no other reason for me to change my views.

Our disagreements concern the content of socialist doctrine. For example, Malia states that "instant socialism following the proletarian seizure of power" was the creed of everybody from Marx to Lenin. If by "instant socialism," Malia means (in his words) "the radiant future hic et nunc" (The Soviet Tragedy, 130), then I completely disagree. Just as an illustration of the sort of things on which I base my views, I will quote one of the foundation texts of prewar Social Democracy, Karl Kautsky's Die Soziale Revolution (1902): even though "a socialist revolution can at a single stroke transfer a factory from capitalist to social property, it is only step by step, through a course of gradual, progressive development, that one may transform a factory from a place of monotonous, repulsive, forced labor into an attractive spot for the joyful activity of happy 